\title{
Patient commentary: Confusing terminology for cancers and precancerous lesions made me anxious
}

\author{
Birte Twisselmann obituaries and editorials editor, The BMJ
}

\begin{abstract}
In 2007, after a "big" birthday, I decided to ask my GP to look at a lesion on my nostril that had been there seemingly forever. I couldn't even say with certainty that I had noticed it grow, but it must have. Driven entirely by vanity, I agreed to have it checked at hospital.

The dermatologist remarked that I must be a sun worshipper, but still I didn't hear the alarm bells ringing. After a long and thorough examination, the dermatologist said, "In my opinion, this is a basal cell carcinoma."

I was stunned-I had not expected anything serious. At least not serious sounding. The word "carcinoma" made me panic momentarily. I had worked at The BMJ for years and as a medical translator, and I had dealt with articles covering all sorts of serious subjects. "Why me?" became "Why not me?" after a helpful chat with a medically trained colleague. And, of course, everyone said: "Well, it's not really cancer-you won't die from it."
\end{abstract}

\section{What if?}

But I couldn't help worrying. What if I hadn't decided to see the doctor then? Would I have ended up with a hole in my face? I had a biopsy in August, a few months after my initial hospital visit, and in October the tumour was excised. I did end up with what felt like an enormous hole in the side of my nose, albeit only for a few weeks. That reinforced my irrational fear that this lesion is called a cancer for a reason.

By December I'd had a splendid skin graft from the side of my face and everything was healing well. Panic subsided until follow-up in February 2008, when I alerted the hospital to a dark stain on the sole of my foot, which also had been there for years if not decades.

The doctor didn't have a name for it and that, surprisingly, was a relief. The lack of a label felt much less threatening, even though the decision to have that excised too raised my anxiety levels, and walking was awkward for a few weeks as I was careful not to split the scar.

The basal cell carcinoma might not have been a "real cancer"-it would not recur or metastasise - but having two suspicious lesions dealt with in less than a year caused me considerable worry at times. There is a lot of body between the nose and the foot.

\section{Lentil shaped mole}

Fast forward to March 2009, when I was checked over once more and discharged. The discharge letter said: "Basal cell carcinoma excised right nose, $0.75 \mathrm{~mm}$ from deep margin," as I expected. Then: "Mildly atypical dysplastic acral lentiginous naevus excised left sole 17th of March 2008, excision complete with $2 \mathrm{~mm}$ margin." What's that when it's at home? A lentil shaped "mole"? For some reason, all that Greek and Latin worried me more than basal cell carcinoma or even the term "rodent ulcer," which friends had used to describe it, two years before.

This phrasing is not a label like cancer, but it felt as if it had a hidden meaning not intended for the patient to understand. This opacity was another trigger for anxiety. Before that letter, a doctor had called it a "mildly cancerous" lesion, so perhaps my worry was well placed.

Competing interests: I have read and understood BMJ policy on declaration of interests and have no relevant interests to declare.

Provenance and peer review: Commissioned; not externally peer reviewed.

Published by the BMJ Publishing Group Limited. For permission to use (where not already granted under a licence) please go to http://group.bmj.com/group/rights-licensing/ permissions 